\begin{tabular}{|c|c|} 
Jurnal Ayurveda Medistra ISSN. 2656-5609| \\
Volume 2 Issue 2 | 2020 | pages:28-32
\end{tabular}

\title{
Hubungan Pandemik Covid-19 Dengan Beban Kerja Perawat Di Puskesmas Pakisjaya Kabupaten Karawang 2020
}

\author{
Kiki Deniati ${ }^{1}$, Karina Novia Ningtyas ${ }^{2}$ \\ 1 Sekolah Tinggi IImu Kesehatan Medistra Indonesia \\ 2 Sekolah Tinggi Ilmu Kesehatan Medistra Indonesia \\ bundacadir@gmail.com, 0895321503032 \\ karinanvn04@gmail.com, 082124653399
}

\begin{abstract}
Workload is a condition when workers are faced with tasks that must be completed on time. Understanding the workload and shortages of health workers, especially nurses, is an urgent effort at this time, during the pandemic there was an increase in the number of patients while the current number of nurses was insufficient and caused an excessive workload for the nurses themselves. This research method used a descriptive analytic design with a cross sectional approach. From the results of the Chi-Square statistical test, it was obtained a p value of 0.003 , it can be concluded that the $p$ value $(0.003)<0.05$, this indicates that there is a relationship between the Covid19 pandemic and the workload of nurses at Pakisjaya Public Health Center, Karawang Regency 2020. The Covid-19 pandemic can affects the workload of nurses at the Pakisjaya Public Health Center, Karawang Regency, when the Covid-19 Pandemic case is high it can increase the workload of nurses to heavy workloads, this heavy ape burden also affects the human resource needs of nurses, if the number of nurses is sufficient, there will be no increase in workload on nurses and nurses can still work productively.
\end{abstract}

Keywords: Covid-19 Pandemic, Nurse Workload

\section{ABSTRAK}

Beban kerja adalah keadaan ketika pekerja dihadapkan pada tugas yang harus diselesaikan tepat waktu. Memahami beban kerja serta kekurangan tenaga kesehatan terutama perawat merupakan upaya yang mendesak saat ini, dimasa pandemik terjadi peningkatan jumlah pasien sementara jumlah tenaga perawat saat ini tidak mencukupi dan menyebabkan beban kerja berlebih untuk perawat itu sendiri. Metode penelitian ini menggunakan desain deskriptif analitik dengan pendekatan cross sectional. Dari hasil uji statistik Chi-Square diperoleh $p$ value sebesar 0,003 dapat disimpulkan $p$ value $(0,003)<0,05$, hal ini menunjukkan bahwa ada hubungan pandemik covid-19 dengan beban kerja perawat di puskesmas pakisjaya kabupaten karawang 2020. Pandemik Covid-19 dapat mempengaruhi beban kerja perawat di Puskesmas Pakisjaya Kabupaten Karawang, ketika kasus Pandemik Covid-19 tinggi dapat meningkatkan beban kerja perawat sampai beban kerja berat, beban kera berat ini juga berpengaruh terhadap kebutuhan SDM perawat, jika jumlah perawat tercukupi maka tidak akan terjadi peningkatan beban kerja pada perawat dan perawat tetap bisa bekerja secara produktif.

Kata Kunci : Pandemik Covid-19, Beban Kerja Perawat 


\section{PENDAHULUAN}

Beban kerja adalah keadaan ketika pekerja dihadapkan pada tugas yang harus diselesaikan tepat waktu (Taufan, Putra dan Prihatsanti, 2016). Menurut Riggio (2015) menyatakan beban kerja adalah tugas-tugas pekerjaan yang menjadi sumber stress seperti pekerjaan mengharuskan bekerja dengan cepat, menghasilkan konsentrasi dari stress kerja. Memahami beban kerja serta kekurangan tenaga kesehatan terutama perawat merupakan upaya yang mendesak saat ini, mengingat kekurangan perawat global dan hubungan antara beban kerja dan retensi perawat (Macphee, Dahinten dan Havaei, 2017). Kondisi ini perlu menjadi perhatian penting dikarenakan jika ini berlanjut akan menjadi dampak untuk pelayanan kesehatan.

Sejak KJS diluncurkan, jumlah pasien meloncak $70 \%$ atau sekitar 500.000 pasien (Kusumawati, 2015) dalam (Aditiya Puspanegara, 2018). Menurut Depkes (2009), disebutkan bahwa pelayanan kesehatan harus memiliki tenaga tetap yang meliputi tenaga medis dan penunjang medis, tenaga keperawatan, tenaga kefarmasian, tenaga manajemen rumah sakit, dan tenaga non kesehatan, serta tenaga tidak tetap dan konsultan sesuai kebutuhan (Rohmat Dwi Romadhoni, 2016).

Selain peningkatan jumlah pasien saat ini COVID-19 telah ditanyatakan sebagai pandemik dunia oleh WHO dan juga telah dinyatakan sebagai Status Keadaan Tertentu Darurat Bencana Wabah Penyakit Akibat Virus Corona oleh Kepala Badan Nasional Penanggulangan Bencana melalui keputusan nomor 9A tahun 2020 dan diperpanjang melalui keputusan nomor 13A tahun 2020. Akibat terjadinya peningkatan kasus dan meluas antar wilayah, pemerintah menerbitkan Peraturan Pemerintah nomor 21 tahun 2020 tentang Pembatasan Nasional Berskala Besar dalam rangka percepatan penanganan Coronavirus Desease 2019 (COVID-19). keputusan tersebut di perbaharui dengan keputusan presiden nomor 12 tahun 2020 tentang penerapan bencana non alam penyebaran COVID-19 sebagai bencana nasional (Direktorat Jenderal Kesehatan Masyarakat, 2020).

Salah satu beban kerja perawat di masa pendemik saat ini adalah intensitas perawatan pasien yang membutuhkan perawatan intensif, selain itu jumlah pasien yang banyak dengan jumlah tenaga perawat yang minim menyebabkan beban kerja berlebih untuk perawat itu sendiri. Sebagian besar pasien COVID-19 yang berkembang menjadi kondisi kritis akan membutuhkan perawatan intensif. Mengingat tantangan dalam mengobati penyakit ini, perawat harus mengelola beban kerja yang berat yang sering membutuhkan prosedur invasif dan tingkat perhatian yang tinggi. Karena itu, menjaga kesehatan fisik dan psikologis perawat dapat memberikan kontribusi besar bagi keberhasilan pengendalian epidemik (Yifan et al., 2020).

Berkaitan dengan judul di atas peneliti melakukan penelitian di Puskesmas Pakisjaya Kabupaten Karawang, karena Puskesmas Pakisjaya merupakan salah satu pelayanan kesehatan yang menerima pemeriksaan Rapid test, menangani kasus Orang Dalam Pemantauan (ODP), dan merujuk kasus Pasien Dalam Pemantauan (PDP) ataupun pasien Positif COVID-19. Selain itu anagka kejadian COVID-19 di Kabupaten Karawang cukup tinggi. Pada Juni 2020 Diskominfo Kabupaten Karawang menyebutkan kasus positif di Kabupaten Karawang mencapai 291. Kondisi ini di prediksi akan mengalami peningkatan dan mengakibatkan peningkatan beban kerja pada perawat yang bekerja di Pelayanan Kesehatan, salah satunya ialah perawat yang bekerja di Puskesmas Pakisjaya Kabupaten Karawang.

\section{METODE PENELITIAN}

Penelitian diatas menggunakan metode penelitian Survey Analitik dengan metode kuantitatif melalui pendekatan Cross Sectional, dimana kedua variabel dapat diukur secara bersamaan. Penelitian ini menganalisis hubungan pandemic COVID-19 dengan beban kerja perawat di Puskemas Pakisjaya Kabupaten Karawang. Populasi dan sampel dalam penelitian ini ialah perawat yang bekerja di Puskesmas Pakisjaya berjumlah 13 orang. Metode sampling yang digunakan adalah Total Sampling dimana Total Sampling ialah suatu teknik penentuan sampel jika semua anggota populasi digunakan sebagai sampel $(H$. Syamsunie Carsel HR, 2018). Menurut Suharsimi (Arikunto, 2010) dalam (Suryani dan Hendryadi, 2010) jika subjek kecil $(<100)$ sebaiknya diambil semua. Waktu penelitian dilakukan pada bulan Agustus 2020 di Puskesmas Pakisjaya Kabupaten Karawang dengan menerapkan protokol kesehatan.

Instrumen penelitian yang digunakan ialah kuesioner terkait pandemik COVID-19 dan 
beban kerja perawat. Kuesioner ini berisikan pertanyaan terkait tanggapan perawat mengenai kejadian pandemik COVID-19 di Kabupaten Karawang dengan pilihan jawaban Tinggi, Sedang dan Rendah. Kemudian, kuesioner beban kerja berjumlah 14 pertanyaan dengan skor skala likert $1=$ Tidak menjadi beban kerja, $2=$ Beban kerja ringan, $3=$ Beban kerja sedang 4= Beban kerja berat.

Prosedur pengelolaan data yang dilakukan pada penelitian ini yaitu Editing, Coding, Entry, Clining, Tabulating, Processing, Kelayakan Instrumen Penelitian (Uji Validitas dan Reliabilitas). Selanjutnya dilakukan analisis menggunakan analisa univariat dan bivariat dengan menggunakan uji Chi Square ( $p$ Value $<0,05$ )

Etika dalam penelitian ini ialah Otonomi, Beneficience, Non-Maleficience, Confidentiality dan Veracity.

\section{HASIL}

A. ANALISA UNIVARIAT

1. Distribusi Frekuensi Pandemik Covid19 Di Puskesmas Pakisjaya Kabupaten Karawang

Tabel 1. Distribusi Frekuensi Pandemik Covid-19 Di Puskesmas Pakisjaya Kabupaten Karawang

\begin{tabular}{cccc}
\hline No & Kategori & $\begin{array}{c}\text { Jumlah } \\
(\mathbf{N})\end{array}$ & $\begin{array}{c}\text { Presentase } \\
(\%)\end{array}$ \\
\hline 1 & Rendah & - & - \\
\hline 2 & Sedang & 3 & 23.1 \\
\hline 3 & Tinggi & $\mathbf{1 0}$ & $\mathbf{7 6 . 9}$ \\
\hline \multicolumn{2}{c}{ TOTAL } & $\mathbf{1 3}$ & $\mathbf{1 0 0}$ \\
\hline
\end{tabular}

Berdasarkan tabel 1 hasil penelitian yang dilakukan pada 13 responden (100\%) mayoritas responden yaitu 10 responden (76.9\%) mengatakan kasus Covid-19 di Puskesmas Pakisjaya dalam Kategori Tinggi.

\section{Distribusi Frekuensi Beban Kerja Perawat Di Puskesmas Pakisjaya Kabupaten Karawang 2020}

Tabel 2. Distribusi Frekuensi Beban Kerja Perawat Di Puskesmas Pakisjaya Kabupaten Karawang

\begin{tabular}{cccc}
\hline No & Kategori & $\begin{array}{c}\text { Frekuensi } \\
\text { (N) }\end{array}$ & $\begin{array}{c}\text { Presentase } \\
(\%)\end{array}$ \\
\hline 1 & Beban & - & - \\
& Kerja & & \\
& Ringan & & \\
\hline
\end{tabular}

\begin{tabular}{cccc}
\hline 2 & $\begin{array}{c}\text { Beban } \\
\text { Kerja } \\
\text { Sedang }\end{array}$ & 4 & 30.8 \\
\hline 3 & $\begin{array}{c}\text { Beban } \\
\text { Kerja } \\
\text { Berat }\end{array}$ & $\mathbf{9}$ & $\mathbf{6 9 . 2}$ \\
\hline & TOTAL & $\mathbf{1 3}$ & $\mathbf{1 0 0}$ \\
\hline
\end{tabular}

Berdasarkan tabel diatas 2 hasil penelitian yang dilakukan pada 13 responden $(100 \%)$ di dapatkan hasil bahwa mayoritas responden mengalami beban kerja berat (nilai kuesioner 42-56) dengan jumlah 9 responden (69.2\%).

\section{B. ANALISA BIVARIAT}

Tabel 3 Hubungan Pandemik Covid-19 Dengan Beban Kerja Perawat Di Puskesmas Pakisjaya Kabupaten Karawang 2020

\begin{tabular}{|c|c|c|c|c|}
\hline \multirow{3}{*}{$\begin{array}{c}\text { Pande } \\
\text { mik } \\
\text { Covid- } \\
19\end{array}$} & \multicolumn{4}{|c|}{ Beban Kerja Perawat } \\
\hline & $\begin{array}{l}\text { Sedan } \\
\text { g }\end{array}$ & Berat & Total & $\begin{array}{c}P \\
\text { Valu } \\
e\end{array}$ \\
\hline & $\overline{\mathbf{N}} \%$ & N \% & $\mathbf{N} \%$ & \\
\hline Sedang & $\begin{array}{l}3 \\
23.1\end{array}$ & 00 & $\begin{array}{l}3 \\
23.1\end{array}$ & 0.00 \\
\hline Tinggi & 17.7 & $\begin{array}{l}9 \\
69.2 \\
\end{array}$ & $\begin{array}{l}10 \\
76.9\end{array}$ & \\
\hline Total & 430.8 & & $\begin{array}{l}13 \\
100\end{array}$ & \\
\hline
\end{tabular}

Berdasarkan tabel 3 hasil analisa tabulasi silang (Cross Tabulation) didapatkan data bahwadari 13 responden (100\%) yang berpendapat kasus Pandemik Covid-19 di Puskesmas Pakisjaya dalam kategori tinggi berjumlah 10 responden $(76.9 \%)$ dengan beban kerja berat berjumlah 9 responden $(69.2 \%)$ dan beban kerja sedang berjumlah 1 responden (7.7\%). Sementara yang berpendapat kasus Pandemik Covid-19 di Puskesmas Pakisjaya dalam kategori sedang dengan beban kerja sedang berjumlah 3 responden $(23.1 \%)$.

Hasil analisa statistik menggunakan Chi Square didapatkan hasil $p$ value sebesar 0.003 maka $p$ value $<0.05(0.003<0.05)$ dapat ditarik kesimpulan bahwa $\mathrm{H}_{0}$ ditolak, yang artinya terdapat hubungan antara Pandemik Covid-19 Dengan Beban Kerja Perawat di Puskesmas Pakisjaya Kabupaten Karawang. 


\section{PEMBAHASAN}

Hasil analisa statistik menggunakan Chi Square didapatkan hasil $p$ value sebesar 0.003 maka $p$ value $<0.05(0.003<0.05)$ dapat ditarik kesimpulan bahwa $\mathrm{H}_{0}$ ditolak, yang artinya terdapat hubungan antara Pandemik Covid-19 Dengan Beban Kerja Perawat di Puskesmas Pakisjaya Kabupaten Karawang.

Berdasarkan hasil penelitian yang dilakukan pada 13 responden (100\%) terdapat 10 responden $(76.9 \%)$ mengatakan kasus Covid-19 di Puskesmas Pakisjaya dalam Kategori Tinggi. kasus yang tinggi ini di dukung dengan rekapitulasi data kasus Covid19 yang didapatkan dari Puskesmas Pakisjaya, data kasus Covid-19 di Puskesmas Pakisjaya mencapai 112 orang.

Berdasarkan rekapitulasi data yang di dapatkan dari Puskesmas Pakisjaya data kasus Covid-19 di Puskesmas Pakisjaya mencapai 112 orang dengan jumlah kasus terbanyak berstatus Orang Tanpa Gejala (OTG) yaitu berjumlah 83 orang $(74.1 \%)$, kemudian status Orang Dalam Pemantauan (ODP) berjumlah 25 orang (22.3\%) dan kasus terbanyak terjadi pada laki-laki yaitu berjumlah 63 orang $(56.2 \%)$ dengan usia antara 20-40 tahun dan kasus meninggal berjumlah 3 orang $(2.7 \%)$ dengan status Pasien Dalam Pemantauan (PDP) dan Positif Covid-19.

Setelah dilakukan penelitian pada 13 perawat $(100 \%)$ yang bekerja di Puskesmas Pakisjaya sebanyak 9 perawat $(69.2 \%)$ mengalami beban kerja berat. Adanya beban kerja berat yang dirasakan dikarenakan beberapa faktor, yaitu faktor internal ataupun eksternal. Sedangkan jenis beban kerja yang dirasakan oleh perawat di Puskesmas Pakisjaya meliputi beban kerja kuantitatif dan beban kerja kualitatif. Namun, walaupun mayoritas merasakan beban kerja berat terdapat 1 responden $(7.7 \%)$ yang beranggapan bahwa beban kerja saat masa pandemik ini masih dalam kategori beban kerja sedang.

COVID-19 telah ditanyatakan sebagai pandemik dunia oleh WHO dan juga telah dinyatakan sebagai Status Keadaan Tertentu Darurat Bencana Wabah Penyakit Akibat Virus Corona oleh Kepala Badan Nasional Penanggulangan Bencana melalui keputusan nomor 9A tahun 2020 dan diperpanjang melalui keputusan nomor 13A tahun 2020 (Direktorat Jenderal Kesehatan Masyarakat, 2020).
Menurut analisa peneliti dari hasil penelitian diatas diketahui bahwa Pandemik Covid-19 memiliki hubungan erat dengan beban kerja perawat. Kasus Pandemik Covid19 yang tinggi atau meningkat dapat meningkatkan beban kerja perawat sampai pada kategori beban kerja berat.

Berdasarkan hasil penelitian diatas kasus Pandemik Covid-19 di Puskesmas Pakisjaya dalam kategori tinggi. Kasus yang tinggi ini di dukung dengan rekapitulasi data kasus Covid-19 yang didapatkan dari Puskesmas Pakisjaya, data kasus Covid-19 di Puskesmas Pakisjaya mencapai 112 orang. Sesuai dengan rekapitulasi data yang didapatkan bahwa jumlah kasus terbanyak Covid-19 yaitu berstatus Orang Tanpa Gejala (OTG) berjumlah 83 orang $(74.1 \%$ ) dan Orang Dalam Pemantauan (ODP) berjumlah 25 orang (22.3\%). Beberapa orang yang berstatus Orang Tanpa Gejala (OTG) terlihat tidak ada tanda gejala Covid-19 yang signifikan namun biasanya memiliki kontak erat dengan kasus Covid-19 atau merasakan beberapa gejala ringan namun memiliki kontak dengan kasus Covid-19 atau merasakan beberapa gejala ringan seperti demam $>38^{\circ} \mathrm{C}$, batuk ataupun nyeri tenggorokan, dan status Orang Tanpa Gejala (OTG) ditegakkan setelah orang tersebut melakukan pemeriksaan Rapid Test yang tersedia di Puskesmas Pakisjaya.

Kasus Pandemik Covid-19 yang tinggi menyebabkan terjadinya peningkatan beban kerja yang berat bagi perawat di Puskesmas Pakisjaya. Adanya beban kerja berat yang dirasakan dikarenakan beberapa faktor, yaitu faktor internal ataupun eksternal. Faktor eksternal ialah tugas yang bersifat fisik ataupun mental diantaranya ialah kondisi lingkungan kerja, tanggung jawab pekerjaan dan sebagainya. Sedangkan jenis beban kerja yang dirasakan oleh perawat di Puskesmas Pakisjaya meliputi beban kerja kuantitatif dan beban kerja kualitatif.

Beban kerja kuantitatif ialah beban berlebih secara fisik ataupun mental, yaitu individu harus melakukan terlalu banyak hal dalam pekerjaannya dan dapat memungkinkan menjadi sumber stress. Beban kerja kuantitatif yang dirasakan oleh perawat di Puskesmas Pakisjaya ialah melakukan observasi klien secara ketat selama jam kerja, kurangnya tenaga perawat banding dengan peningkatan jumlah klien selama pandemik covid-19, banyaknya pekerjaan dan beragamnya pekerjaan yang 
harus dikerjakan. Sedangkan, beban kerja kualitatif adalah beban kerja pada individu di akibatkan tuntutan pekerjaan yang lebih tinggi dari batas kemampuan kognitif dan teknis individu tersebut. Beban kerja kualitatif yang dirasakan oleh perawat di Puskesmas Pakisjaya ialah kondisi klien dan keluarga klien yang tidak kooperatif dengan kecemasan meningkat, dan memburuknya kondisi klien secara tiba-tiba, selain itu keterbatasan APD juga dapat menjadi beban kerja bagi perawat di Puskesmas Pakisjaya

(Wu et al., 2020) Menyampaikan Negara-negara pandemik akan terkena dampak pada dokter dan perawat. Jumlah tahunan pengalaman kerja, jumlah jam kerja perminggu, frekuensi pekerjaan, dan jumlah personil dalam tim atau praktek seseorang dapat berkaitan dengan kelelahan atau beban kerja. Kondisi pandemik Covid-19 juga menyebabkan kelelahan dalam waktu yang lama dibanding sebelum terjadinya pandemik Covid-19. Perawat yang bekerja merasa kurang kendali atas kebijakan dan prosedur baru yang diberlakukan untuk staf, kondisi pasien yang butuh perawatan intensif juga menjadi salah satu faktornya. Perawat yang bekerja di garis depan penanganan Covid-19 tidak hanya berada pada lingkungan yang berbeda, tetapi juga berlatih dilingkungan yang tegang.

\section{PENUTUP}

Berdasarkan hasil penelitian dan pembahasan yang telah dikemukakan sebelumnya, maka dapat ditarik kesimpulan dari hasil analisis secara keseluruhan yaitu sebagai berikut :

1. Distribusi Frekuensi Pandemik Covid-19 di Puskesmas Pakisjaya dalam kategori tinggi.

2. Distribusi frekuensi beban kerja perawat di Puskesmas Pakisjaya mayoritas mengalami beban kerja berat.

3. Terdapat hubungan antara Pandemik Covid-19 Dengan Beban Kerja Perawat di Puskesmas Pakisjaya Kabupaten Karawang

\section{DAFTAR PUSTAKA}

$\begin{array}{lr}\text { 1. Aditiya Puspanegara } & (2018) \\ \text { "PENGARUH } & \text { TINGKAT } \\ \text { KETERGANTUNGAN PASIEN } \\ \text { TERHADAP BEBAN } & \text { KERJA } \\ \text { PERAWAT RSPI PROF DR. } & \text { PULIANTI SAROSO," hal. 46-51. }\end{array}$

2. Afriia Lesty, R. et al. (2017) "Hubungan beban kerja perawat dengan kinerja perawat di bangsal instalasi rawat inap rsud mardi waluyo kota blitar," 1(1), hal. 43-50.

3. Direktorat Jenderal Kesehatan Masyarakat (2020) "PANDEMIK COVID-19."

4. H. Syamsunie Carsel HR (2018) "Metodelogi Penelitian Kesehatan Dan Pendidikan."

5. Kemenkes RI (2020) "Pedoman Pencegahan dan Pengendalian Coronavirus Disease (COVID-19) revisi IV," Germas, hal. 0-115.

6. Macphee, M., Dahinten, V. S. dan Havaei, F. (2017) "administrative sciences The Impact of Heavy Perceived Nurse Workloads on Patient and Nurse Outcomes," hal. 117. doi: $10.3390 /$ admsci7010007.

7. Riadi, A. (2020) "PEDOMAN PENCEGAHAN DAN PENGENDALIAN CORONAVIRUS DISEASE (COVID-19)," Kementrian Kesehatan Republik Indonesia, 5, hal. 1-214. doi: 10.33654/math.v4i0.299.

8. Suryani dan Hendryadi (tanpa tanggal) "Metode Riset Kuantitatif Teori Dan Aplikasi Pada Penelitian Bidang Managemen Islam," hal. 2010.

9. Taufan, M., Putra, P. dan Prihatsanti, U. (2016) "Hubungan Antara Beban Kerja Dengan Intensi Turnover Pada Karyawan Di Pt. 'X,'” Empati, 5(2), hal. 303-307.

10. Wu, Y. et al. (2020) "A comparison of burnout frequency among oncology physicians and nurses working on the front lines and usual wards during the COVID-19 epidemic in Wuhan, China," Journal of Pain and Symptom Management. American Academy of Hospice and Palliative Medicine. doi: 10.1016/j.jpainsymman.2020.04.008.

11. Yifan, T. et al. (2020) "Symptom Cluster of ICU nurses treating COVID-19 pneumonia patients in Wuhan, China," Journal of Pain and Symptom Management. American Academy of Hospice and Palliative Medicine. doi: 10.1016/j.jpainsymman.2020.03.039. 